\section{Vol. 65, No. 13}

In the report, "Mycobacterium abscessus Infections Among Patients of a Pediatric Dentistry Practice - Georgia, 2015," on page 355 , the first sentence should have read, "All water samples from the seven dental stations had bacterial counts above the $\mathbf{C D C}$ recommended $\leq 500$ colony-forming units $(\mathrm{CFU}) / \mathrm{mL}$ (average $=91,333 \mathrm{CFU} / \mathrm{mL}) ; M$. abscessus was isolated from all water samples (3).”

\section{Vol. 65, No. 18}

In the report, "Reduced Incidence of Chikungunya Virus Infection in Communities with Ongoing Aedes Aegypti Mosquito Trap Intervention Studies - Salinas and Guayama, Puerto Rico, November 2015-February 2016," the last sentence of the fifth paragraph should have read, "After adjustment for sample design, the proportion of chikungunya virus $\operatorname{IgG}$ antibody among participants from the two intervention communities was one half that of participants from nonintervention communities (risk ratio $=0.52,95 \%$ confidence interval $=0.38-0.71$ ) (Table). "The report was first published online as an Early Release on May 10, 2016, and is now contained in this regular May 13 issue.

In the report, "Interim Guidance for Zika Virus Testing of Urine - United States, 2016," the second sentence of the second paragraph should have read, "Zika virus rRT-PCR testing of urine should be performed in conjunction with serum testing (8)." The report was first published online as an Early Release on May 10, 2016, and is now contained in this regular May 13 issue. 